\title{
Teaching Practice Research on Information Literacy Education Based on MOOC
}

\author{
Sujuan Zhang \\ Heilongjiang Bayi Agricultural University, Daqing, China \\ Email: librarycf@163.com
}

How to cite this paper: Zhang, S.J. (2019) Teaching Practice Research on Information Literacy Education Based on MOOC. Journal of Service Science and Management, 12, 126-131.

https://doi.org/10.4236/jssm.2019.122008

Received: December 19, 2018

Accepted: January 30, 2019

Published: February 2, 2019

Copyright $\odot 2019$ by author(s) and Scientific Research Publishing Inc. This work is licensed under the Creative Commons Attribution-NonCommercial International License (CC BY-NC 4.0). http://creativecommons.org/licenses/by-nc/4.0/

\begin{abstract}
This paper discusses the introduction of MOOC resources into the teaching of information literacy education, and designs the teaching practice of information literacy education course under the participation of MOOC with the cross mode of the relationship between MOOC and traditional teaching. Students learn the course contents by means of independent inquiry, group cooperation, and interactive discussion, etc. Teachers guide the teaching process by means of combining network resources with classroom discussion to achieve good teaching results.
\end{abstract}

\section{Keywords}

MOOC, Information Literacy, Teaching Practice Research

\section{About MOOC}

MOOC (massive open online courses) is an acronym of massive, open, online, and courses, referring to the massive open online course. It consists of many learners willing to share and coordinate to enhance knowledge. MOOC has attracted a wide spread attention and become a hot topic of discussion in education teaching field [1]. In 2012, the "first year of MOOC" was launched, and many top universities in many countries successively set up online learning platforms to offer free courses online. According to incomplete statistics, since 2008, more than 13,000 MOOCs have been set up all over the world [2]. In 2013, Horizon Report of New Media Consortium (NMC) (Higher Education Edition) pointed out that higher education would offer large-scale online open courses, which would be widely used by universities [3]. MOOC learning is an informal learning way based on interest, which is a personalized learning way with active participation, and a social learning way and a rich media learning way [4], and 
the integration of network and higher education. Horizon Report of New Media Consortium (Basic Education Edition) in 2014 pointed out that the application of hybrid learning design should be strengthened in next 3 - 5 years, and the hybrid learning mode combines the best advantages of classroom teaching and online learning [5]. Opening education resources and MOOC has become a driving force for the development strategy of colleges and universities, helping teachers and students master online participatory learning methods, actively exploring and deepening the innovation of college courses and teaching modes, and guiding teachers to introduce open education resources into their classroom teaching [6].

\section{Information Literacy Education}

As a general education course in the university, the information literacy education is generally set up as an elective course "Literature Retrieval and Utilization" in the whole university. GUIDELINES ON INFORMATION LITERACY FOR LIFELONG LEARNING formulated IFLA in 2006 provides a practical framework information literacy education and courses. Students prepare study activities before class, design practical courses in or after class, and accept information literacy education through independent courses and extracurricular courses and other ways [7]. In 2013, IFLA Trend Report pointed out that the increasing number of digital resources made information literacy skills more important, the value of digital world to information literacy skills was increasing, and those without information literacy skills, basic literacy skills and Internet technology would increasingly face obstacles to social integration [8]. Colleges and universities carry out education for new students, lecture training and embedded courses by classroom teaching and network learning, so as to cultivate and improve college students' information consciousness, information ability, information ethics, and consciousness, foresight and independence of using information.

\section{Introduction of MOOC into Information Literacy Classroom Teaching Practice}

The relationships between $\mathrm{MOOC}$ and traditional teaching can be summarized into three types: parallel mode, which requires students to study similar courses in other schools online while conducting class teaching; coincidence mode, which uses MOOC course teaching online to change face-to-face teaching into class discussion form; cross mode, which mainly focuses on the original course design, embedding or citing MOOC course contents as course resources [9]. The second and third modes can be regarded as blended teaching, which combines the advantages of traditional learning styles with the advantages of E-Learning (i.e. digital or networked learning). It should not only give full play to the leading role of teachers in guiding, inspiring and monitoring the teaching process, but also fully reflect the initiative, enthusiasm and creativity of students as the 
main body of the learning process [10]. The author designed the teaching plan of information literacy education course combined with MOOC, which is based on the cross mode in the relationship between MOOC and traditional teaching, and chose the Information Retrieval written by the teacher Huang Ruhua of Wuhan University and the Document Management and Information Analysis written by the teacher Luo Shaofeng of the University of Science and Technology of China on the MOOC-iCourse website as the important reference courses for classroom teaching in the practical teaching of classes with information literacy courses.

\section{Information Literacy Course Design Based on MOOC}

\subsection{Teachers' Preparation for the Course}

In order to effectively carry out the blended teaching activities combined with MOOC, teachers should have a good understanding of the students' majors, learning needs and motivation, integrate the students' learning needs, learning contents with teaching objectives, and divide the learning contents into small learning units. Teachers should learn the contents of Information Retrieval written by teacher Huang Ruhua of Wuhan University and Document Management and Information Analysis written by teacher Luo Shaofeng of university of science and technology of China in advance, and choose the contents related to the course as the reference for class teaching. Teachers also need to ask students to register in real name on the iCourse website, read the course introduction, join the QQ and Wechat discussion groups created by teachers, divide students into groups of 5 - 6 people, and requires the students to watch and complete the assigned homework before each class, and have class discussion and online discussion on the assigned homework in the form of group.

\subsection{Design of Teaching Activities}

The specific class teaching activities should be designed according to the contents of pre-divided learning units, the contents of online learning of the students and the teaching objectives. Teachers play a leading role in the whole teaching activity. They will arrange the contents of network resources that require students to learn in advance according to the teaching progress, understand the students' mastery degree of the required learning contents through class teaching, guide the students to put forward the difficult problems, good methods and viewpoints in learning through class discussion, and focus on the key contents and student questions in the classroom according to the feedback from the students in the class discussion.

\subsection{Learning Evaluation}

The learning result of the course should be evaluated in a multivariate way combining the quality of course assignment, online course test score and performance in class discussion. This evaluation method examines the performance of students in the whole learning process from all aspects. Compared with the sin- 
gle evaluation method of completely relying on exams in the past, it is more conducive to mobilize the enthusiasm of students to participate in learning activities, reduce the disadvantages of students not studying at ordinary times and making sudden review before exams, and develop good learning habits.

\section{Experience}

By the above teaching practice, in the beginning of the first two weeks, the author obviously feels changes on students. In the past, there is always no response when asking "Do you have any questions?" in the classroom teaching, and most students are lazy and distracted, but after using this teaching mode, students are very active for presentation in classroom teaching. In addition, a lot of new ideas and new methods have been put forward in the discussion group. There are also many students in the discussion group on one issue. The completion rate and the quality of students' homework, and the teaching effect have been improved obviously. Summarize the teaching practice process, we have such experience as follows:

1) Do a good job in resource selection High quality and diversified course resources are the important foundation of blended teaching in the network environment. According to the teaching plan, various high-quality resources are gathered to provide good references for teachers to design the course content and pass it on to the students in a way that is acceptable to them.

2) Choose the appropriate interactive platform Use the simple and easy-to-use interactive platform as teaching aids, which provides course introduction, learning suggestions, learning arrangements and so on. Many learning contents can be discussed on the platform. The author chooses QQ and Wechat, which are commonly used by students, as the learning interactive platform, to discuss the learning content by means of words, pictures, network links and voice. Teaching resources and related learning materials can be directly uploaded to the learning discussion group for students to download and study, which is very convenient and practical.

3) Do a good job in classroom teaching organization [11] Classroom teaching is an important way to stimulate and maintain learning motivation. Through classroom teaching, teachers can understand the students' mastery of the key content of the course. Classroom discussion is the continuation and deepening of online discussion. Before classroom teaching, students should finish the network materials required to study and watch, so as to ensure that students have a full understanding of the content of classroom discussions, and can ask questions they do not understand in the classroom, and teachers can then talk about the questions more thoroughly when giving lessons. The key teaching points in the classroom is students' questions in learning. For example, when learning with RSS reader, I assigned my students to study the content of Teacher Luo Shaofeng's "Document Management and Information Analysis" for the fifth week, and asked them to download and install an RSS reader by themselves, and 
to subscribe to some specified blogs, websites, electronic journals and other contents, also asked them to show their RSS readers in groups, and to ask questions by themselves in the use of RSS in class next week. Because of the preparation of study and practice before class, the students showed their RSS readers in class, some problems and skills of usage that should be paid attention to in the use of RSS readers were proposed. The students spoke enthusiastically, and some questions were solved by the students themselves in the discussion. The author sorted out the problems and then chose the key and difficult questions to answer for the students. Through such learning, students would gain more, especially in the analysis of typical mistakes, which was very helpful to clarify students' retrieval thoughts. Through pre-class learning, the students' ability to learn independently was cultivated, also classroom discussion and communication were conducive to cultivating students' critical thinking, enabling students to grasp the methods of solving problems and develop the habit of thinking from multiple perspectives and in an all-round way. Therefore, the organization of classroom teaching was a very important part of this teaching practice.

\section{Epilogue}

The large-scale application of MOOC means that it has the opportunity to create a new and more equitable educational pattern, but not all universities have the ability to use MOOC. For students, online education is completely free, but for many universities, it seems that it is a heavy burden. Costs such as payments for the production of courses, teachers' salaries and payments for platform use often make those less famous universities not be able to continue and go on with the development [12]. Therefore, applying MOOC to information literacy education curriculum is a beneficial attempt; teachers should choose suitable teaching links and teaching system design content. Teachers should pay more attention to the preparation of class and classroom teaching, so as to achieve better teaching effect, so that students can acquire well and perform better in class. This study is an exploratory teaching practice study, which is expected to provide references for relevant teaching reform.

\section{Funding}

This paper is Heilongjiang Bayi Agricultural University Support Program for San Heng San Zong (Project Number: ZDTDJH201801) and research results of Heilongjiang art science planning project (Project Number: 2017B094).

\section{Conflicts of Interest}

The author declares no conflicts of interest regarding the publication of this paper.

\section{References}

[1] Mu, Z.S. and Dong, B.J. (2014) Exploration of Blended Learning Mode Based on 
MOOC-A Case Study of Coursera Platform. Modern Educational Technology, No. 5, 73-80.

[2] Liu, L.H., Xia, S.F. and Jia, C.L. (2016) Theoretical Teaching Thinking on Digital Media Direction in Software Engineering under the Background of MOOC. Education and Teaching Forum, No. 36, 228-229.

[3] Johnson, L., Adams Becker, S., Cummins, M., et al. (2013) NMC Horizon Report: 2013 Higher Education Edition. The New Media Edition, New Media Consortium, Austin, TX.

[4] Xie, C.H., Yuan, H.Y. and Deng, S.S. (2014) Study on Enterprise Learning Management System Based on Characteristics of MOOC. Human Resource Development of China, No. 13, 18-23.

[5] Johnson, L., Adams Becker, S., Estrada, V., et al. (2014) NMC Horizon Report: 2014 Higher Education Edition. The New Media Edition, New Media Consortium, Austin, TX.

[6] Hao, D. (2013) Document Analysis on the Research Status of MOOC in China. Distance Education in China, No. 11, 42-50.

[7] ILFA (2018) Guidelines on Information Literacy for Lifelong Learning. http://www.ifla.org/files/assets/information-literacy/publications/ifla-guidelines-en. pdf

[8] IFLA (2018) IFLA Trends Report. https://www.ifla.org/node/7942

[9] Wang, Q. (2013) MOOCs Change Traditional Teaching. China Education Information, No. 19, 26-28.

[10] He, K.K. (2004) New Development of Education Technology Theory from Blending Learning (Volume One). E-Education Research, No. 3, 1-6.

[11] Yu, S.Q., Lu, Q.L. and Chen, S.J. (2005) Blended Teaching under Network Environment-A New Teaching Mode. China University Teaching, No. 10, 50-56.

[12] Wang, L.M. (2018) Study on Element Influence on Satisfaction of Learner in SPOC Teaching among Universities. Lanzhou University, Lanzhou. 